\title{
Corporate Governance and its impact on Performance of Automobile Industry of Pakistan: The Role of Foreigner Members in BOD
}

\author{
Wang PeiZhi ${ }^{*}$, a and Muhammad Ramzan ${ }^{2, b}$, \\ ${ }^{1}$ Dean at School of International Trade and Economics, Shandong University of Finance and \\ Economics, Jinan, China \\ ${ }^{2}$ Ph.D. Scholar at Shandong University of Finance and Economics, Jinan, China \\ asheila_guo1988@hotmail.com, bramzanmehar7@gmail.com \\ ${ }^{*}$ Corresponding author
}

\begin{abstract}
Keywords: Automobile Industry, Corporate Governance, Firm Performance, and Pakistan Stock Exchange.
\end{abstract}

\begin{abstract}
Pakistan's automobile sector goes through trouble phase from many years; however, from the last half-decade, it reflects as an emerging sector of Pakistan stock exchange (PSX). The research is to explore the relations of foreign representatives' inboard and the firm's performance with the contemplation of outliers' problem. The study draws special attention by focusing on a gap that never been revealed yet. We examined 12 years of annual data with a robust regression model to treat the outliers. The results reported that the foreigners on board are the primary gauge for the remarkable financial performance of the firms. The board size and audit committees showed up with proper accountability in the system. However, the finding for independent directors and institutional investors presented a negative relation with the firm's performance. The findings of this research will be serving as a base for policymakers of the emerging automobile industry of Pakistan for the financial betterment of the companies.
\end{abstract}

\section{Introduction}

There are many different concepts presented the definition of corporate governance as the process through which the companies are managed and governed. [1] The scholars argue that corporate governance is important for both the boards and the shareowners. Many other definitions have established that the meaning of corporate governance is to control and supervise the company's management or its managerial conduct [2]. One notion of corporate governance is that it creates links between shareholders, boards, and other stakeholders [3]. Accordingly, the performance of the corporations is considered to be an important and vital part of the boards' duties because it relates to the financial resources that are used to achieve the overall aim of an organization. So the governance and well-specified board help the organizations to protect the resources with efficiency and create greater value for the shareholders [4]. All countries in the world set their own governance rules for corporations according to their political, social, and religious needs [5]. Experts said the rules are predefined in white and black, which provides the guarantee that all the rights of the shareholders are protected [6]. There is a large number of countries that have set their own rules for their corporations, and this process became speed up after the American SOX-Act of 2002 [7]. Similarly, the SECP of Pakistan the only government institution that is responsible for corporations' governance in the country.

The study objective is to measure the relationship between corporate governance and the firms' performance. In particular, we are going to explore the relation of foreigner members in BOD with the performance of the firms through a contemplation of the outliers because the outlier problem is common in these types of observation. 


\section{Literature review and hypotheses development}

This section provides a detailed review of already published materials relating to corporate governance and the firm's financial performance. So this section divided into the following subsections.

\subsection{Board size and firm performance}

[8-9] the scholars argued that there are two different schools of thought endorsed the relationship among the board size and a corporations' performance. The first school of thought claims that the small-sized board of directors will contribute more effectively to push to the top of the firms [10-11]. Whereas, the second school of thought emphasizes the role of the larger board size on better performance of the companies [12-13]. Similarly, some other studies have shown that under the complex environment of businesses and challenging organizational culture, a large size of the board supports to run the firm more efficiently [14, 30-31]. The others argued that the large size of the board collects large size of information [15]. Moreover, the opponent scholars have taken the case of Vietnam because of differences in Vietnams' management culture as compared to international practices, and they established that the increase in board size causes to decrease in the delegation of the board [16].

H1: The positive association between board size and performance of the companies.

\subsection{Female board and firm performance}

Many similar studies on corporations' governance \& the role of women already existed and the experts believed that the female members are like a change in the characteristics of the board [17-18]. A female board member brings a positive attitude within the firm; As a result, the firm's performance affected directly or indirectly due to the existence of female members [19-20]. It means the board size can be studied based upon the dimensions such as female presence in BOD [21]. [22] The scholars strongly argued that the existence of female board members links with excellent firm performance because of the advantage of public relations and communications with underprivileged clients. Similarly, the female directors also give relational and human capital to the firms because they play an indispensable role in improving the overall performance by showing a proactive attitude [22].

H2: The association among female board members and the companies' performance is positive.

\subsection{Board independent directors and firm performance}

The previous study suggested that the firm's performance increases with the addition of independent directors. [23] The scholars found that there is more financial pressure due to high directors on the board. Moreover, there is less chance of bankruptcy when the firm has many independent directors [24]. The agency theory said the board of directors is responsible for monitoring the management and safeguarding the interests of the shareholders. The separation of labor among board and management results in added agency problems costs to the firm and friction between shareholders and management [25]. However, some researches argued that the division of independent directors leads to enhance stable monitoring, which causes higher firm performance [26-27].

H3: The positive association among independent board members and the firms' performance.

\subsection{Institutional Investors representation in board and firm performance}

[28] scholars proposed that the encouragement level of the board members become high due to the board's owners. The ownership of the board is a more efficient way of board inspiration [29]. [30] the empirical evidence of this investigation shows that the ownership of board and firm performance is positively associated. Another study suggested that there is a non-linear relationship between board ownership and performance [31]. [32] The researchers said that the board ownership contribution is considered as the ' two-edged knife' as an optimum level of ownership of the board contributes positively to firm performance.

H4: The board ownership and performance of the firm ha a positive association. 


\subsection{Audit committee and firm performance}

The audit committees play their role by checking the firm's in-house and external auditors to safeguard the shareholder's equity and interest [33]. Meanwhile, the risk of fraudulent financial reporting reduces due to the audit committee [34-35]. Scholars endorsed establishing the audit committees for assurance of the performance of firms' governance, and the auditor report should be added yearly in the firm statement [36]. Similarly, the availability of more international audit firms is considered a positive sign of good corporate governance because these types of firms provide a high quality of auditing services [37-38].

H5: The positive association among the audit committee and the performance of the firm.

\subsection{Foreigner members in BOD and firm performance}

In this section, we discuss a new emerging factor that may use to measure the corporate governance of developing nations, which is a representation of foreigners in BOD. Sometimes the corporations of developing nations fail to follow the governance rules solely via local members due to the riskier unhealthy environment at workplace; So in this situation, the existence of foreign members in BOD increases the probability to obey the rules of governance because of foreigner's positive and the healthier outlook experience and interest [39]. The scholars already used this factor with the name of Anglo-American members in firms of Norway and Sweden for corporate governance in 2003. After that, research conducted on the other aspect of foreigner members which is the equity ownership of foreigner members and its influence on the value of the Korean firms in 2004 and they concluded that there is a positive and significant relationship between firm values and the equity ownership by foreigners. The researchers claim that the values of firms significantly increase during the presence of Anglo-American members in BOD while recently founded that the Anglo-American members in the internal board have more effect instead of their representations as independent board members. Similarly, we hypothetically think that foreigner members' influence in firms may be higher in developing nations like Pakistan. The only research found who conducted recently using foreign nationality holders board members as a factor of CG and established that board members with different nationalities have a negative relation with the performance of the firms.

The study focuses the gap of research found in Pakistan that this particular component and its effect on the performance of the firms yet not utilizes appropriately as it may be compulsory to find out the relationship of said component for the reference and recommendations about the cultivation of managerial policies and their implementation at developing nations. The second gap found from previous studies that no anyone who takes care of outliers during the study of governance as this problem even the common in such kinds of variables' observations.

H6: There is a positive association among foreign board members and the performance of the firm.

\section{Econometric tools and methodology}

\subsection{Methodology}

We used a panel dataset of the emerging automobile industry of Pakistan from 2006-2017 with annual frequency. We focused on listed firms of Pakistan stock exchange (PSX) because no company has found to close down or merged during a particular period. The data of 12 cross-sections have obtained from the official website of Pakistan stock exchange (PSX). Thus, our sample involves a complete list of automobile assemblers with a total of 144 observations. Before applying the OLS estimator, we have checked all the assumptions of classical regression. Initially, we used VIF analysis as it is considered the best technique to discover the multicollinearity issue. Furthermore, the Breusch-Pagan test has applied for heteroskedasticity, and leverage analysis has examined to quantify and detect the outliers. After that, we applied the different methods of OLS estimators, including panel OLS, fixed-effects, and random-effect. A Hausman test calculated the p-value 0.003 that suggests more appropriate results in the fixed-effect model. Moreover, We have found some outliers in our variable observation. Therefore, a robust regression model used to treat the outliers in our study [26]. 
Table 1. Descriptions and Label of Variables

\begin{tabular}{ccc}
\hline Variables & Labels & Descriptions \\
\hline Firm Performance: Return on Ast. & ROA & A ratio of firms EAT and total assets \\
\hline Governance: Board of Directors & BOD & An elected group who represent the shareholders \\
\hline Independent Directors & Ind_D & Board members who do not have material relation with company \\
\hline Executive Directors & Ex_D & A managing director of the company \\
\hline Institutional Investors & Ins_I & Institution representative in the board of directors \\
\hline No. of Audit Committee & Ad_C & Committees who oversee the financial statements \\
\hline Female Directors & Fem_D & A female representative in BOD \\
\hline Foreigner Member in BOD & Fm_D & Foreigner members in BOD \\
\hline Control Variables: Log of Assets & Ln_A & Natural log of total assets of the firm \\
\hline Log of Capital & Ln_C & Natural log of the total capital of the firm
\end{tabular}

Source: The Authors

\section{Data analysis and discussions}

\subsection{Correlation analysis}

Many scholars suggested that the best way to find out the strength of the connection between firms' governance and financial performance of the corporations is correlation analysis. Meanwhile, the results of the Pearson analysis of correlation are as follows:

Table 2. Correlation Analysis

\begin{tabular}{|c|c|c|c|c|c|c|c|c|c|c|}
\hline Variables & ROA & BOD & Ind_D & Ex_D & FemD & Ins_I & Ad_C & Fm_D & Ln_A & Ln_C \\
\hline ROA & 1.0000 & & & & & & & & & \\
\hline BOD & 0.3330 & 1.0000 & & & & & & & & \\
\hline Ind_D & 0.1986 & 0.1612 & 1.0000 & & & & & & & \\
\hline Ex_D & -0.1320 & -0.2892 & 0.2472 & 1.0000 & & & & & & \\
\hline Fem_D & -0.1253 & -0.2269 & 0.2537 & 0.8859 & 1.0000 & & & & & \\
\hline Ins_I & 0.0368 & -0.0336 & 0.1654 & 0.1641 & -0.089 & 1.0000 & & & & \\
\hline Ad_C & 0.3438 & 0.2930 & -0.025 & -0.270 & -0.249 & -0.0545 & 1.0000 & & & \\
\hline Fm_D & 0.4266 & 0.2493 & -0.330 & -0.197 & -0.137 & 0.1573 & 0.1348 & 1.0000 & & \\
\hline Ln_A & -0.0225 & 0.0969 & -0.062 & -0.041 & -0.039 & -0.0480 & -0.0406 & -0.0827 & 1.0000 & \\
\hline Ln_C & -0.5089 & -0.2352 & 0.1822 & 0.3655 & 0.4467 & -0.1568 & -0.2339 & -0.3600 & 0.0184 & 1.0000 \\
\hline
\end{tabular}

Source: The Authors' Investigation

The results depict the positive association among the board of directors, independent directors, institutional investors, numbers of audit committees, and firm performance. All other components of governance have a negative association with the automobile firm's performance. Interestingly, the result also shows the positive relationship between newly included factors for corporate governance, which is foreigner board members, and firm performance as 0.42 value shows in the above-listed table.

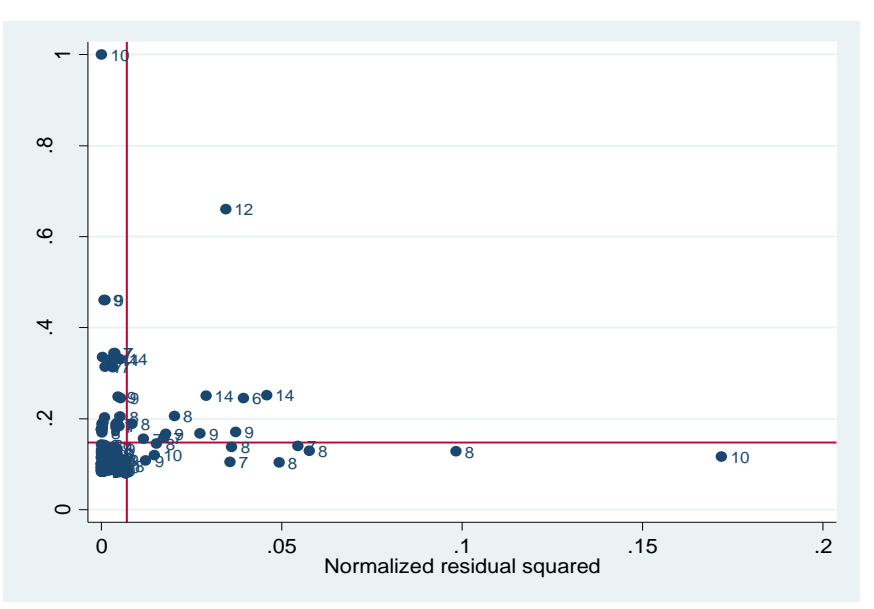

Graph 1. The diagnostic outliers plot using Leverage Source: The Authors' Investigation
Table 3. The VIF Test for the Independent Variables

\begin{tabular}{ccc}
\hline Variables & VIF & 1/VIF \\
\hline BOD & 1.40 & 0.714359 \\
\hline Ind_D & 1.51 & 0.661112 \\
\hline Ex_D & 7.42 & 0.134826 \\
\hline Fem_D & 7.70 & 0.129818 \\
\hline Ins_I & 1.70 & 0.587109 \\
\hline Ad_C & 1.17 & 0.856155 \\
\hline Fm_D & 1.64 & 0.609450 \\
\hline Ln_A & 1.05 & 0.955376 \\
\hline Ln_C & 1.47 & 0.679214 \\
\hline Mean VIF & 2.78 & \\
\hline Source: The Authors' Investigation
\end{tabular}


The measures of OLS estimation always disturb when we have outliers in our observations, so the best way to avoid outliers is to apply robust regression. The robust regression is a good measure for obtaining the best value of the slope and intercept when you have outliers because it does not exclude or ignore the outliers from our observations, however, it is treated as an observation with giving those outliers a less weight. The above-listed graph 1 shows the leverage analysis of outliers, and according to this, our variables' observations have both vertical and bad outliers that are not good for the simple OLS estimators.

The VIF test is the test of multicollinearity assumption of the classical regression model. Multicollinearity is considering a problem that may disturb the results of the OLS regression model. According to the outcome of our analysis, there is no predictor found with the linear relationship, so it means there is no collinear independent in our model, and there is no issue of multicollinearity.

\subsection{Impact of corporate governance on firm performance}

The measurement of effects of predictors on response variables can be obtained from the fixed effect and random effect model of the OLS estimator when we have a panel dataset [37-38]. The fixed effect is our focused test because we want to assume within a variation of the cross-sections is constant, but it does not work in the presence of outliers. Therefore, we have applied robust regression for the correct measures of the objectives of the study. The following table shows the results of all estimation techniques, respectively:

$$
\begin{gathered}
\mathrm{ROA}_{i t}=\beta 0+\beta 1\left(\mathrm{CG}_{i t}\right)+\varepsilon_{i t} \\
\mathrm{ROA}_{i t}=\alpha 0+\beta 1\left(\mathrm{CG}_{i t}\right)+\gamma \mathrm{Z}_{\mathrm{it}}+\eta_{\mathrm{i}}+v_{\mathrm{t}}+\mathrm{u}_{\mathrm{it}} \\
\mathrm{ROA}_{\mathrm{it}}=\alpha_{0}+\beta_{1}\left(\mathrm{CG}_{\mathrm{it}}\right)+\gamma \mathrm{Z}_{\mathrm{it}}+\eta_{\mathrm{i}}+v_{\mathrm{t}}+\mathrm{u}_{\mathrm{it}}+\varepsilon_{\mathrm{it}} \\
\mathrm{ROA}_{\mathrm{it}}=\left(\mathrm{CG}_{\mathrm{it}}\right) \beta+\gamma+\varepsilon, \varepsilon \sim \mathrm{N}\left(0, \sigma^{2} \mathrm{I}\right)
\end{gathered}
$$

Here, $\mathrm{ROA}_{i t}$ is the ratio for all included firms $\mathrm{i}$ at time $\mathrm{t}$; ROA is a response variable in this case; $\mathrm{CG}$ vector used for all components of corporate governance; $\alpha \mathrm{o}$ is the unknown intercept for each entity, $\mathrm{Z}$ vector denotes for control variables which are the firm size; log assets and log capital used as a proxy for firm size; $\eta$ i represents firm fixed effect which assume within variation is constant; $v_{t}$ is for the time-fixed effect. $U_{i t}$ is for between entity error, and $\varepsilon_{i t}$ is for within entity error; In $4^{\text {th }}$ model, $\mathrm{ROA}=\left(\mathrm{y}_{1}, \cdots, \mathrm{y}_{\mathrm{n}}\right)^{\mathrm{T}}, \mathrm{CG}=\left(\mathrm{x}_{1}, \ldots, \mathrm{x}_{\mathrm{n}}\right)^{\mathrm{T}}$, denoted for outliers treatments as $\gamma_{\mathrm{i}}$ shows shift parameter is nonzero when i observation is an outlier and zero, otherwise.

Table 4. Panel OLS, Fixed Effect, GLS Random Effect, and Robust Regression Model

\begin{tabular}{ccccc}
\hline Variable & OLS & Fixed & Random & Robust \\
\hline BOD & $4.6265^{* *}$ & $9.1813^{* * *}$ & $7.0969^{* * *}$ & $.0306^{* *}$ \\
\hline Ind_D & -9.3149 & 4.9756 & 1.2224 & -.0349 \\
\hline Ex_D & 2.3574 & 1.9969 & 1.4569 & .0059 \\
\hline Fem_D & 7.2102 & -3.2372 & 7.6852 & .0943 \\
\hline Ins_I & -.1237 & -.7062 & -.5052 & -.0007 \\
\hline Ad_C & $2.1835^{* *}$ & $4.4209^{* *}$ & $2.5348^{*}$ & $.0179^{* * *}$ \\
\hline Fm_D & $2.5902^{*}$ & .1706 & 2.1334 & $.0119^{*}$ \\
\hline Ln_A & -6.367 & 2.461 & 9.033 & $-.0758^{* * *}$ \\
\hline Ln_C & $-4.4198^{* * *}$ & $-9.5711^{* * *}$ & $-7.5973 * * *$ & $.0366^{* * *}$ \\
\hline Constant & 22.8363 & $61.9486 *$ & $48.6007^{*}$ & $.4799^{* * *}$ \\
\hline $\mathrm{R}^{2}$ & .4326 & .5056 & .3923 & .5704 \\
\hline Adj. $\mathrm{R}^{2}$ & .3948 & .4239 & .3522 & .5471 \\
\hline $\mathrm{N}$ & 144 & 144 & 144 & 144
\end{tabular}

Source: The Authors' Investigation

Note: This table shows the Panel OLS model results with using firm performance as an outcome variable. The values shown in the above table are coefficient values of the variables with starts of the t-statistics significance value as at the $*$ for $5 \%$, ** for $10 \%$, and $* * *$ for $1 \%$ levels, respectively. Model 1, is about the OLS panel fixed effect regression model, model 2, shows the OLS panel random effect regression model, model 3 shows the results of simple OLS regression and model 4 shows the results of Robust regression. Random model overall $\mathrm{R}^{2}$ value taken.

The simple OLS results show the four out of seven factors of corporate governance are significant at a different level, while two of them are insignificant. The independent directors and institutional 
investors have a negative relation with the performance of the firms, while our main exciting factor that is foreigner members in BOD has a positive and significant relationship with the outcome variable. The outcomes of the fixed effect are almost the same as the OLS model; according to results, there are four components of corporate governance that have a significant relationship with the performance, but we reject our two hypotheses against the relationship of female directorship and the board ownership. The fixed and random effect is tackling the problem of heterogeneity and multicollinearity, but these are unable to measure the correct and consistent relationship in the existence of outliers. So our study mainly focuses on this issue and the test for outliers already discussed in our last paragraph. The diagnostic check for outliers shows many observations with extreme values, and therefore we applied our 4th model that is robust regression. The results of this technique show that the four components and intercept is significant at a different level, but others are insignificant. The independent directors and institutional investors have negative relations with performance but others all have a positive and significant relationship with the performance of the firms, this result is similar to the results many other scholars. It means the large size of the BOD and numbers of audit committees in the automobile industry of Pakistan cause to create a better financial performance. The foreigner in BOD also has a positive and significant effect on the firms' performance; this finding is against the results of recently conducted research on foreigner equity holders. We accept the hypothesis of foreigner members against the firms' performance; as a result, it shows foreigners in a team of the board cause a positive change for the financial performance of the corporations. The value of R2, in this case, shows the variation of $57 \%$ in firms' financial performance explained by the all included components of corporate governance.

\section{Conclusion and suggestions}

The study objective is to test the relation of corporate governance especially, the foreigner members on the board, with the firms' performance. According to our final model, corporate governance has a positive influence to enhance the financial performance of the firms. To be concluded, implementations of governance rules at the workplace increase the efficiency of the management work that leads to an increase in the capacity of firms' performance through skillful managers. The size of the board, numbers of audit committees, and the foreigners on the board causes significant and positive to enhance the performance. The results of the control variables and intercept also showed up significant. We accept the hypotheses for all governance factors and reject the hypotheses of independent directors and institutional investors because of having negatively insignificant relations to financial performance. Executive directors and female representation in the board also associated positive by their performance, but the result shows insignificant. We have seen the poorly consistent performance of executive-level directors in Pakistan because, in the majority of cases, no hight executive wants to interrupt and make some changes at the operational level. This is also due to the different hierarchal system with less strength of female board members, as the results of these two components are similar to the finding others. The finding of the number of audit committees shows the positive contribution of the accounting finance and the audit department that ensures the regular check and complaints on SECP rules. Therefore, it gives a guarantee of a firm's performance by protecting its financial corruption. The role of foreigners in the BOD is performing well and contributing well to enhance the financial condition of firms by dutiful and skillful attitude, while some researchers also revealed the negative impact. The managers of developing nations shall take these findings of this research under consideration while implementing the governance policies and strategies for accomplishing the goals for maximizing the shareholder wealth.

\section{References}

[1] Linck, J., Netter, J. M., \& T. Yang. (2007). the Determinants of Board Structure. Journal of Financial Economics, forthcoming.

[2] Lehn, Kenneth, Patro, S., \& Zhao, M. (2003). Determinants of the Size and Structure of Corporate Boards. Working Paper, University of Pittsburgh, 1-66. 
[3] Hermalin, E, B., \& Weisbach, M. S. (1991). The Effects of Board Composition Incentives on and Direct Firm Performance. Financial Management, 20, 101-112.

[4] Jensen, C, M., \& Murphy, K. J. (1990). Performance Pay and Top-Management Incentives. Journal of Political Economy, 98, 225-264.

[5] Adams, R., \& Ferreira, D. (2007). "A Theory of Friendly Boards. Journal of Finance, 62(1).

[6] Burkart, M. (1995). Initial Shareholdings and Overbidding in Takeover Contests. Journal of Finance, 50, 1491-1515.

[7] Denis, D., \& Denis, D. (1994). Majority Owner managers and Organizational Efficiency. The Journal of Corporate Finance, 1, 91-118.

[8] Cremers, Martijn, \& Nair, V. (2005). Governance Mechanisms and Equity Prices. Journal of Finance, 60, 2859-2894.

[9] Foundation, B. M. (2011). BBVA Microfinance Foundation. . Universal Corporate Governance Code for Microfinance Institutions. Working Paper, 1-88.

[10]Hartzell, Jay, \& Starks, L. (2003). Institutional Investors and Executive Compensation. Journal of Finance, 58, 2351-2374.

[11]Raheja, C. G. (2005). Determinants of Board Size and Composition: A theory of. Journal of Financial and Quantitative Analysis, 40, 283-306.

[12]Lipton, M., \& Lorsch, J. (1992). A modest Proposal for Improved Corporate Governance. Business Lawyer, 48(1), 59-77.

[13] Yermack, D. (1996). "Higher Market Valuation of Companies with a Small Board of Directors. Journal of Financial Economics, 40(2), 185-211.

[14]Mak, Teen, Y., \& Kusnadi, Y. (2001). Size Really Matters Further Evidence On The Negative Relationship Between Board Size And Firm Value. Pacific-Basin Finance Journal,13(1

[15]Pfeffer, J. (1972). Size and Composition of Corporate Boards of Directors: The Organization and its Environment. Administrative Science Quarterly, 17(2), 218-228.

[16]Klein, A. (1998). Firm Performance and Board Committee Structure. Journal of Law and Economics, 41(1), 275-303.

[17]Coles, J. L., \& Naveen, L. (2008). Boards: Does one size fit all? Journal of Financial Economics, 87(2), 329-356.

[18]Baysinger, D., B., \& Butler, H. N. (1985). Corporate Governance and the Board of Directors: Performance Effects of Changes In Board Composition. Journal of Law, Economics and Organization, 1, 101-124.

[19] Vafeas \& Nikos. (1999). Board Meeting Frequency and Firm Performance. Journal of Financial Economics, 53, 133-142.

[20]Adams, \& B, R. (2005). What Do Boards Do? Evidence from Committee Meeting and Director Compensation Data. Working Paper, Federal Reserve Bank of New York, 1- 38.

[21]Dalton, D., \& al, R. e. (1999). "Number of Directors and Financial Performance: A Meta-Analysis. The Academy of Management Journal, 42(6), 674-686.

[22] Ardalan, K. (2008). On the Role of Paradigms in Finance. Routledge Aldershot, England.

[23]Dutta, P., \& Bose, S. (2006). Gender Diversity in the Boardroom and Financial Performance of Commercial Banks: Evidence from Bangladesh. The Cost and Management, 34(6), 70-74.

[24]Li, H., Meng, L., Wang, Q., \& Zhou, L. (2008). Political Connections, Financing and Firm Performance: Evidence from Chinese Private Firms. Journal of Development Economics, 87(1).

[25]Hubbard, Glenn, R., \& Palia, D. (1995). Executive Pay and Performance Evidence from the U.S. Banking Industry. Journal of Financial Economics, 39, 105-130.

[26]Bassem, B. S. (2009). Governance and Performance of Microfinance Institutions in Mediterranean Countries. Journal of Business Economics and Management, 10(1), 31-43.

[27]Thrikawala, S. L. (2013). Corporate Governance-Performance Relationship in Microfinance Institutions (MFIs). Asian Journal of Finance and Accounting, 5(1). 
[28]Elloumi, F., \& P., G. J. (2001). Financial Distress and Corporate Governance: An Empirical Analysis. Corporate Governance, 1(1), 15-23.

[29]Frank, M. Z., \& Goyal, V. K. (2009). Capital Structure Decisions: Which Factors are reliably important? Financial Management, 38, 1-37.

[30]Jensen, M. C. (1983). Organization Theory and Methodology. The Accounting Review, 8(2).

[31]Wu, X., \& Li, H. (2015). Board Independence and the Quality of Board Monitoring: Evidence from China. International Journal of Managerial Finance, 11(3), 308-328.

[32]Brown, L., \& M.L, C. (2004). Corporate Governance and Firm Performance. Journal of Accounting and Public Policy, 25(4), 409-434.

[33]Duru, A., Iyengar, R., \& Zampelli, E. (2016). The Dynamic Relationship between CEO Duality and Firm Performance: The Moderating Role of Board Independence. Journal of Business Research, 69(3), 4269-4277.

[34]Brickley, J., A., L. R., \& Smith, J. C. (1988). “Ownership Structure and Voting on Antitakeover Amendments. Journal of Financial Economics, 20, 267-291.

[35]Himmelberg, P., C., Hubbard, Glenn, R., \& Darius Palia. (1999). Understanding the Determinants of Managerial Ownership and the Link between Ownership and Performance. Journal of Financial Economics, 53, 353-384.

[36]Morck, Randall, Shleifer, A., \& Vishny, R. W. (1988). Management Ownership and Market Valuation. Journal of Financial Economics, 20, 293-315.

[37]Berle, A., \& Means, G. (1932). The Modern Corporation and Private Property. Macmillan NewYork, 1-56.

[38]Demsetz, H. (1983). The Structure of Ownership and the Theory of Firm. Journal of Law and Economics, 26, 375-390.

[39]Mehran, H. (1995). Executive Compensation Structure, Ownership, and Firm Performance. Journal of Financial Economics, 38(2), 163-184. 